\title{
Bitkisel tasarımların formal (biçimsel) estetik model bağlamında değerlendirilmesi: Antalya Konyaaltı bölgesi
}

\section{Estimation of the aesthetics on planting designs in the term of the formal aesthetic model: A case study in Antalya Konyaalti region}

\author{
Hilmi Ekin OKTAY ${ }^{\circledR}$, Reyhan ERDOĞAN² \\ ${ }^{1}$ Van Yüzüncü Yıl Üniversitesi, Mimarlık ve Tasarım Fakültesi, Peyzaj Mimarlığı Bölümü, Zeve Kampüsü, Van \\ ${ }^{2}$ Akdeniz Üniversitesi, Mimarlık Fakültesi, Peyzaj Mimarlığı Bölümü, Kampüs Antalya \\ Sorumlu yazar (Corresponding author): H. E. Oktay, e-posta (e-mail): ekinoktay@yyu.edu.tr \\ Yazar(lar) e-posta (Author e-mail): reyhanerdogan@akdeniz.edu.tr
}

\section{MAKALE BİLGİSİ}

Alınış tarihi 01 Temmuz 2019

Düzeltilme tarihi 30 Ekim 2019

Kabul tarihi 31 Ekim 2019

\section{Anahtar Kelimeler:}

Bitkisel tasarım

Kullanicı tercihleri

Uzman tercihleri

Formal estetik
Öz

Çalışma kapsamında kullanıcı ve peyzaj mimarlarının bitkisel tasarımlara ilişkin tercihlerini saptamak amacıyla anket çalışması yürütülmüştür. Bu bağlamda 400 kullanıcı anketi ve 51 peyzaj mimarı anketi gerçekleştirilmiştir. Bulgular değerlendirildiğinde, yapılan regresyon analizleri göstermiştir ki, peyzaj mimarlarının bitkisel tasarım hakkında tercihlerini en çok etkileyen bitkisel tasarım unsurları Vurgu, Denge ve Doğallıktır. Bunun yanında kullanıcıların bitkisel tasarım hakkında tercihlerini en çok etkileyen bitkisel tasarım unsurları ise Vurgu ve Dengedir.

\section{ARTICLE INFO}

Received 01 July 2019

Received in revised form 30 October 2019

Accepted 31 October 2019

\section{Keywords:}

Planting design

Lay-person preferences

Expert preferences

Formal aesthetics

\begin{abstract}
Within the scope of the study, a survey was conducted to determine the preferences of users and landscape architects for planting designs. In this context, the survey was conducted with the number of 400 users and 51 landscape architects. When the findings are evaluated, the regression analyses showed that the planting design elements of Emphasis, Balance and Naturalness are the most influential factors on the landscape design preferences of landscape architects. Moreover, most influential factors on the landscape design preference of users Emphasis and Balance.
\end{abstract}

\section{Giriş}

Peyzaj, günlük hayatımızın önemli bir bölümünü içinde geçirdiğimiz ya da içinde olmasak bile; çalışırken, seyahat ederken, yemek yerken veya dinlenirken uzaktan da olsa seyrettiğimiz, duyumsadığımız bir bütündür. Doğal öğelerin başat olduğu bir peyzajda bulunma, stres sonrası zihninin toparlanmasına yardımcı olmaktadır (Kaplan ve ark. 1998). Bunun yanında yine doğal bir peyzajda belli bir süre boyunca bulunmak, dikkat gerektiren işlerin daha başarıyla yapılmasına (Hartig ve ark. 1991) yardımcı olduğu çalışmalarla ortaya konulmuştur. Haftada üç kez günde en az yarım saat doğa içinde aktivitede bulunmak ameliyat sonrası kanserin tedavi edilmesine (Cimprich 1992), yine pencereden bakış dahi olsa da doğal öğelerin başat olduğu bir peyzajı görmek bile ameliyat sonrası daha az ağrı kesici kullanımına (Ulrich 1984) ve öğrencilerin derslerinde daha başarılı olmasına (Tennessen ve Cimprich 1995) katkı sağlamaktadır. Kısacası doğal unsurların hâkim olduğu peyzajlar insan sağlığına olumlu katkılar sağlamaktadır (Kaplan ve ark. 1998). Bunun yanında yapılan çalışmalar göstermiştir ki doğal manzaralar, kentsel manzaralara nazaran daha çok kiși tarafından, daha fazla beğenilerek, daha çok tercih edilmektedir (Kaplan ve Kaplan 1989). İnsanlar, kentsel ya da doğal fark etmeksizin tercih edilen mekanlarda, tercih edilmeyen mekânlara göre daha fazla kalmayı ve bu mekânları daha çok vakit geçirmeyi ve bu mekânda daha çok bulunmay1 istemekteyken (Nasar 1992, Kaplan ve ark. 1998), tercih edilmeyen mekânlar üzerinde başka tasarrufların olabilmesinin muhtemel olduğu da bilinmektedir (Kaplan ve ark. 1998). Tercihler ise beğeni ile ilişkilidir ve bu da beğeni 
üzerine düşünce üreten estetik öğretisi ile yakından ilişkilidir (Ekşioğlu 2010). Bu yüzden hayatımızın önemli bir kısmını içinde veya ona maruz kalarak geçirdiğimiz peyzajların ve bu peyzajların oluşmasını sağlayan peyzaj tasarımlarının değerlendirilmesinde estetik konusu önem taşımaktadır.

Peyzaj kavramının içeriği ve bağlamı, kavramı ele alan kişinin bakış açısı ve uzmanlaşması çerçevesinde farklılıklar göstermekle birlikte, çevre ile peyzaj arasındaki kavramsal farklılıkların altını çizmenin faydası vardır. Birçok kuramcı peyzaj tanımının altında insanın algısının önemini vurgulamıştır. Örneğin Bourassa (1991) peyzaj1, çevrenin algılanan bölümü olarak tanımlarken, Meinig (1979) peyzajın çevremizdeki her şeyden oluştuğunu; ancak bunun peyzajla çevrenin aynı şey olduğu anlamına gelmediğini belirtmiştir. Bu bakımdan çevre, yaşayan her şeyin doğasında doğal olarak bulunan bir mülkiyet ve bizi çevreleyen, yaşamımızı devam ettirmemizi sağlayan bizi saran bir dış dünya iken peyzaj daha özel, daha bağımlı, yaşamımızı devam ettirmemize direkt olarak bağl1 olamayan özelliktedir. Peyzaj bir anlamda Meinig (1979)'in de belirttiği gibi, bizim görüşümüzle tanımladığımız ve zihnimizle yorumlanmış olan bir çevre parçasıdır.

Peyzajlar üzerine olan tercihi açıklamak için çok sayıda estetik teorisi geliştirilmiştir. $\mathrm{Bu}$ teorilerin başında Formal Estetik teorisi (Bell 1999), Bilgi İşleme Teorisi (Kaplan ve Kaplan 1989, Kaplan ve ark. 1998), Savana Hipotezi (Orians 1980), Korunaklı mekan açık görüş (prospect-refuge) teorisi (Appleton 1975) ve Biofili Hipotezi (Wilson 1984) gelmektedir. Bu çalışmada geștalt ilkelerine yaptığı vurguyla dikkat çeken ve özellikle uzmanların tasarımlarında çokça yararlanmış olduğu Formal Estetik Teori üzerinde durulmuş ve bu teorinin bileşenleri incelenmiştir.

$\mathrm{Bu}$ önemin bilincinde olarak, bu çalışmada Antalya Konyaaltı bölgesindeki peyzaj tasarımlarının önemli bir bileşeni olan bitkisel tasarımlar hakkında önceki çalışmalarda oluşturulan kuramsal bilgiler doğrultusunda hazırlanan ampirik bir çalışmadan yola çıkarak, peyzaj tasarımlarının değerlendirilmesinde estetiğe ilişkin genel bir değerlendirme yapılmaya çalışılmıştır.

$\mathrm{Bu}$ araştırmada Antalya Kenti Konyaaltı Bölgesi örneğinde kamusal açık alanları kullanıcıların nasıl değerlendirdiği örneklenen mekânlara ilişkin duyusal değerlendirme sıfatlarına verdikleri cevaplarla ve yine bu mekânlara ilişkin verdikleri beğeni puanı ile saptanmaya çalışılmıştır.

Antalya'nın beş merkez ilçesinden biri olan ve son on yılda hızlı bir kentleşme süreci yaşayan Antalya Konyaaltı'nda yürütülmüş olan bu çalışmanın amaçları;

Konyaaltı bölgesinde bulunan peyzaj tasarımlarının en önemli unsuru olan bitkisel tasarımların değerlendirmesinin yapilmas1,

Konyaaltı bölgesinde bulunan peyzaj tasarımının en önemli bileşeni olan uygulanmış bitkisel tasarımlara ilişkin kullanıcıların ve peyzaj mimarlarının görüş ve tutumlarının belirlenmesi,

Peyzaj mimarı ve kullanıcı tutumları arasındaki farklılıkların ortaya konulması,

Kullanıcı ve peyzaj mimarlarının beğenisini etkileyen temel tasarım ilkelerinin saptanmasıdır.

\section{Materyal ve Yöntem}

Çalıșma alanı olarak belirlenen alan, Konyaaltı beldesinin kentsel bölgesidir. Çalışma alanı, kuzeyde Hürriyet Caddesi, batıda Batı Antalya Çevre Yolu ve Olimpos Beydağları Milli Park1, güneyde Konyaaltı plajları ve doğuda Dumlupınar Bulvarıyla sınırlanmıştır. Akarsu varlığı açısından zengin olan alan, Arapsuyu Deresi ve Boğaçay Akarsuyu'nu içinde barındırır. Alanın Güneybatısında yer alan Antalya Limanı önemli bir ticaret ve ulaşım merkezidir (Şekil 1).

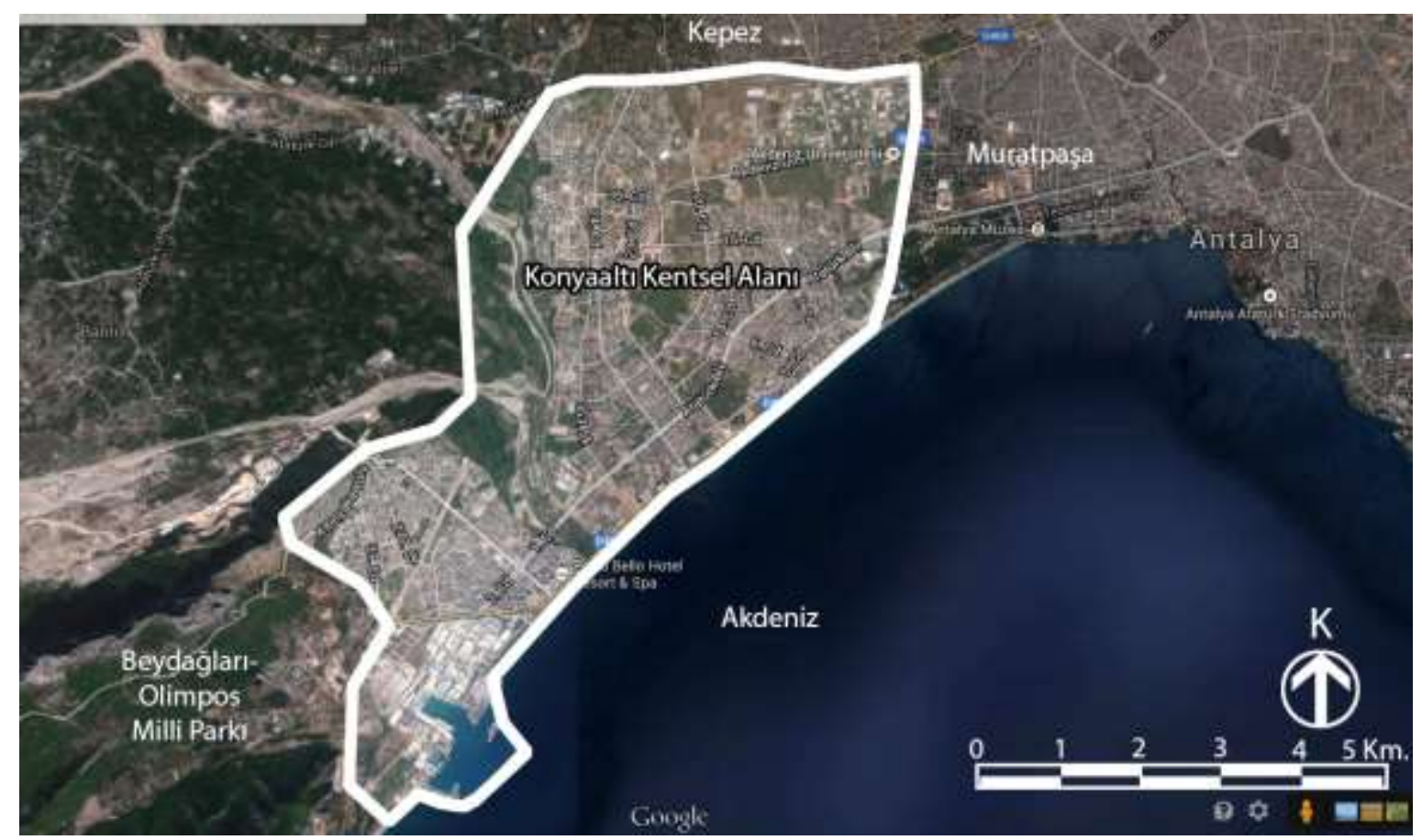

Şekil 1. Çalışma alanı Konyaaltı.

Figure 1. Study area Konyaalti. 
Çalışma alanı özellikle kentsel nitelikli alanlarda bulunan kentsel yeşil alanları kapsamaktadır. Alana ilişkin nüfus sayımı verileri, peyzaj ve çevre estetiği ile ilgili literatür, alanda çekilmiş fotoğraflar, anket verileri, sözlü görüşme ses kayıtları araştırmanın temel materyallerini oluşturmaktadır.

Çalışma; ofis çalışmaları, arazi çalışmaları, anketlerin uygulanması, sonuçların değerlendirilmesi ile nicel veriye ilişkin genel değerlendirme olmak üzere beş aşamada yürütülmüştür. Bu aşamada Konyaaltı'nın farklı yerlerinden 347 fotoğraf kullanılmıştır. Fotoğraflar, 18-135 mm. F/3.5-5.6 odak açıklığına sahip bir lens takılı olan Dijital Tek Lensli Yansıtmalı Kamera (DSLR) yardımıyla, 72 dpi., 20 megapiksel çözünürlüklü olarak, 20 Nisan 2016 tarihinde saat 10 ile 18 saatleri arasında, havanın açık ve güneşli olduğu bir periyotta çekilmiştir. Fotoğraf çekiminde bitkisel tasarım dışındaki unsurların fotoğraf karesi içerisine mümkün olduğunca girmemesine çalışılmıştır (bitkisel tasarımlar açısından özel tasarımları ifade eden 4 fotoğraf dışında).

Araştırmada kullanılmıș olan yöntem, daha önce birçok araştırmacı (Kaplan ve ark. 1972; Nasar 1992; Hershberger 1992; Kaplan ve ark. 1998; Çakcı 2007; Ekşioğlu 2010) tarafından kullanılmış, güvenilir bir yöntem olan ve psiko analiz alanında kullanılan "görsellerle sorgulama" yöntemidir.

Buradan hareketle 10 apiori kategori altında (tekrar, aralıklı tekrar, vurgu, çeşitlilik, büyük ölçek, kurakçıl bitkiler, makiler, tekdüze tasarımlar, doğal koruluklar, küçük ölçekli tasarımlar), parklardan ve yeşil alanlardan çekilen 347 fotoğraftan, her kategori için 5 fotoğraf olmak üzere, toplamda 50 fotoğraf seçilmiştir.

Peyzaj estetiğinin değerlendirilmesinde uzman görüşleri ile kullanıc1 görüşlerinin ne ölçüde örtüştüğü ya da ayrıştığını saptamak önemlidir. Bunun yanında mekânın fiziksel özelliklerinin değerlendirilmesinde bu konuda eğitim almış kişilerin değerlendirmelerine ihtiyaç vardır. Bunun için hem peyzaj mimarlarının beğeni puanlarını tespit etmek hem de mekânların fiziksel özelliklerinin hangi tasarım unsurları ile açıklanabildiğini bulmak amacıyla peyzaj mimarlarına yönelik bir anket çalışması gerçekleştirilmiştir. Peyzaj mimarları için beğeniyorum-beğenmiyorum maddesinin yanında fotoğraflarda tespit edilen tasarım unsuları olan, vurgu, tekrar, aralıklı tekrar, renk, çeșitlilik, doğallık, ölçek ve denge de ankete eklenmiștir. Peyzaj mimarlarından fotoğrafta gördükleri manzaraya, belirtilen tasarım unsuru için 1-5 arasında bir puan vermeleri istenmiştir. 1 en düşük, yani tasarım unsurunun bulunmamasını, 5 ise en yüksek değeri yani tasarım unsurunun yoğun bir şekilde var olduğunu ifade etmektedir. Bu bağlamda 50 fotoğrafı 9 başlık altında değerlendirmesinin istendiği 450 değişkenli 51 anket peyzaj mimarları gibi bitkisel tasarım disiplini konusunda uzmanlara Haziran-Ağustos 2016 tarihleri arasında uygulanmıştır.

Bunun yanında kullanıcıların mekânı nasıl algıladığı üzerine de bir anket düzenlenmiștir. Bu ankette temel soru kullanıcıların mekânı ne kadar beğendiğidir. Kullanıcılardan belirtilen fotoğraf için 1-5 arasında bir puan vermesi istenmiştir. 1 en düşük, yani o mekânın hiç beğenilmediğini o mekânın hiç memnun edici olmadığ $\breve{v}_{1}$ ve çok boş olduğunu ifade ederken 5 ise en yüksek değeri yani o mekânın çok beğenildiğini, o mekânın çok memnun edici olduğunu ve o mekânın çok yoğun duygular hissettirdiğini ifade etmektedir.

Çalışma alanının bulunduğu yerleşim yeri olan Konyaaltı ilçesinde 2014 yılının adrese dayalı nüfus sayımlarına göre 145648 kişi yaşamaktadır (Türkiye İstatistik Kurumu 2016).
Örneklem büyüklügünün saptanmasında tesadüfi örnekleme yöntemi kullanılmıştır. Çalışmada anket sayısını belirlemek için Yazıcıoğlu ve Erdoğan (2007)'da belirtilen örneklem büyüklüğü tablosu dikkate alınarak, $\alpha=0.05$ (standart hata) için \pm 0.05 örnekleme hatası ile evren büyüklügü 100000'un üzerindeki nüfus için öngörülen en az 384 denek sayısı temel alınmıştır. Sonuç olarak; Haziran-Eylül 2016 tarihleri arasında 400 adet anket, parklar ve yeşil alanlarda gönüllülük esas tutularak, rastgele seçim ile yüz yüze görüşme tekniği kullanılarak yapılmıştır.

Anketlerin değerlendirilmesinde Faktör analizi, regresyon analizi ve tek yönlü Anova ve T-testi kullanılmıştır. Regresyon modelleri ise tasarım unsurları ile beğeni arasındaki ilişkinin, bilgi işleme teorisi değişkenleri ile beğeni arasındaki ilişkinin, Bilgi İşleme Teorisi değişkenleri ile tasarım unsurları arasındaki ilişkinin ve demografik değişkenlerle beğeni arasındaki ilişkinin saptanmasında kullanılmıştır.

\section{Bulgular}

Ankete katılan 51 peyzaj mimarının demografik bilgileri Çizelge1'de verilmiştir. Buna göre katılımcıların 38'i (\%74.5) kadın kalan 13'ü (\%25.5) ise erkektir. Katılımcıların \%66.7 gibi bir oranda olan çoğunluğunun otuz yaşın altında olduğu görülmektedir.

Ankete katılanların 28'i (\%54.9) en son lisans derecesinde bir eğitime sahiptir. Katılımcılardan büyük çoğunluğu olan 17 kişi (\%33.3) ise özel sektörde çalışmaktadır.

Katılımcılardan 14 kişinin (\%27.5) asgari ücret ve altında gelire sahiptir.

Ankete katılan 400 kullanıcının demografik bilgileri Çizelge 2'de verilmiştir. Buna göre katılımcıların \%56'sı kadın kalan $\% 44$ 'ü ise erkektir.

Katılımcıların \%5.7'i 15-18 yaş arasında, \%28.2'si 19-29 yaş aralığında, \%44.8 gibi bir oranda olan çoğunluğunun 30-49 yaş aralığında olduğu görülmektedir. 50-65 yaş arasındaki katılımcılar \%17.3'ü oluştururken katılımcıların16's1 (\%4) 65 yaş ve üstündedir.

Ankete katılanların 4'ü (\%1) okur/yazarken, 9'u (\%2.2) ilkokul derecesinde, 12'si (\%3) ortaokul, 99'u (\%24.8) lise derecesinde, 71'i (\%17.8) önlisans, 153'ü (\%38.2) lisans, 40'1 (\%10) yüksek lisans seviyesindeyken, 12'si (\%3) en son doktora düzeyinde eğitime sahiptir.

Katılımcılardan 17 kişi (\%4.2) işçi, 61 kişi (\%15.2) özel sektörde çalışırken, 23'ü (\%5.8) serbest meslek, 125'i (\%31.2) memur, 4'ü (\%1) esnaf, 48'i (\%12) emekli, 73'ü (\%18.3) öğrenci, 25'i (\%6.3) ev hanımı, 8'i (\%2) işsizken, 16's1 diğer kategorisinde yer almaktadır.

Katılımcıların aylık gelirlerine bakıldığında 99 kişinin (\%24.8) asgari ücret ve altı, 41 kişinin (\%10.2) 950-1500 TL, 77 kişinin (\%19.2) 1501-2500 TL, 91 kişinin (\%22.8) 25013500 TL, 46 kişinin (\%11.5) 3501-4500 TL ve yine 46 kişinin (\%11.5) ise 4501 TL ve üzeri bir gelire sahip olduğu gözlenmiştir.

Bunun yanında peyzaj mimarlarının tasarım unsurlarına verdikleri cevaplar arasındaki güvenirlik ölçülmüş (Çizelge 3) ve genel olarak bütün tasarım unsurlarına verilen cevapların cronbach $\alpha$ değeri 0.95 olarak bulunmuştur. $\mathrm{Bu}$ da verilen cevapların büyük oranda güvenilir olduğuna işaret etmektedir.

Çizelge 3 incelendiğinde uzmanların üzerinde en çok hem fikir olduğu konunun bitkisel tasarımın doğallığı olduğu 
Çizelge 1. Ankete katılan peyzaj mimarlarının demografik dağılımı.

Table 2. Result of demographical frequency analysis of experts.

\begin{tabular}{|c|c|c|c|c|c|c|}
\hline Cinsiyet & Kadın & Erkek & & & & \\
\hline $\mathrm{N}$ & 38 & 13 & & & & \\
\hline$\%$ & 74.5 & 25.5 & & & & \\
\hline Yaş & $19-29$ & $30-49$ & $50-65$ & 65 ve üstü & & \\
\hline $\mathrm{N}$ & 34 & 16 & 1 & - & & \\
\hline$\%$ & 66.7 & 31.4 & 2 & & & \\
\hline Eğitim Durumu & Lisans & Yüksek Lisans & Doktora & & & \\
\hline $\mathrm{N}$ & 28 & 16 & 7 & & & \\
\hline$\%$ & 54.9 & 31.4 & 13.7 & & & \\
\hline Çalıştığı Kurum & İşsiz & Üniversite & Kamu & Özel Sektör & & \\
\hline $\mathrm{N}$ & 15 & 15 & 4 & 17 & & \\
\hline$\%$ & 29.4 & 29.4 & 7.8 & 33.3 & & \\
\hline Aylık Gelir, TL & Asgari ücret ve altı & $950-1500$ & $1501-2500$ & $2501-3500$ & $3501-4500$ & 4501 ve üstü \\
\hline $\mathrm{N}$ & 14 & 5 & 7 & 6 & 12 & 7 \\
\hline$\%$ & 27.5 & 9.8 & 13.7 & 11.8 & 23.5 & 13.7 \\
\hline
\end{tabular}

Çizelge 2. Ankete katılan kullanıcıların demografik dağılımı.

Table 2. Result of demographical frequency analysis of lay persons.

\begin{tabular}{|c|c|c|c|c|c|c|c|c|c|c|}
\hline Cinsiyet & Kadın & Erkek & & & & & & & & \\
\hline $\mathrm{N}$ & 224 & 176 & & & & & & & & \\
\hline$\%$ & 56.0 & 44.0 & & & & & & & & \\
\hline Yaş & $15-18$ & $19-29$ & $30-49$ & $50-65$ & 65 ve üstü & & & & & \\
\hline $\mathrm{N}$ & 23 & 113 & 179 & 69 & 16 & & & & & \\
\hline$\%$ & 5.7 & 28.2 & 44.8 & 17.3 & 4.0 & & & & & \\
\hline Eğitim Durumu & Okur/Yazar & İlkokul & Orta Öğr. & Lise & Önlisans & Lisans & Yüks & Lisans & & tora \\
\hline $\mathrm{N}$ & 4 & 9 & 12 & 99 & 71 & 153 & 40 & & 12 & \\
\hline$\%$ & 1.0 & 2.2 & 3.0 & 24.8 & 17.8 & 38.2 & 10.0 & & 3.0 & \\
\hline Meslek & İşçi & Özel Sektör & Serbest Meslek & Memur & Esnaf & Emekli & Öğr. & Ev han. & İşsiz & Diğer \\
\hline $\mathrm{N}$ & 17 & 61 & 23 & 125 & 4 & 48 & 73 & 25 & 8 & 16 \\
\hline$\%$ & 4.2 & 15.2 & 5.8 & 31.2 & 1.0 & 12.0 & 18.3 & 6.3 & 2.0 & 4.0 \\
\hline $\begin{array}{c}\text { Aylık Gelir, } \\
\text { TL }\end{array}$ & $\begin{array}{c}\text { Asgari ücret ve } \\
\text { altı }\end{array}$ & $950-1500$ & $1501-2500$ & $\begin{array}{c}2501- \\
3500\end{array}$ & $3501-4500$ & $\begin{array}{c}4501 \mathrm{ve} \\
\text { üstü }\end{array}$ & & & & \\
\hline $\mathrm{N}$ & 99 & 41 & 77 & 91 & 46 & 46 & & & & \\
\hline$\%$ & 24.8 & 10.2 & 19.2 & 22.8 & 11.5 & 11.5 & & & & \\
\hline
\end{tabular}

Çizelge 3. Bitkisel tasarım unsurlarının ölçümünün karakteristiği.

Table 3. Result of reliability analysis of expert's choices of indicators.

\begin{tabular}{|c|c|c|c|c|}
\hline \multirow[b]{2}{*}{ Tasarım Unsuru } & \multirow[b]{2}{*}{ Uzmanlar Arası Güvenirlik (Cronbach $\alpha$ ) } & \multirow[b]{2}{*}{$\mathrm{r}$} & \multicolumn{2}{|c|}{ Fotoğraflardaki Varyasyon } \\
\hline & & & $\bar{x}$ & S \\
\hline Vurgulu-Vurgusuz & 0.946 & 0.26 & 3.14 & 1.15 \\
\hline Tekrarl1-Tekrar Etmeyen & 0.965 & 0.34 & 3.26 & 1.24 \\
\hline Aralıklı Tekrar var - Aralıklı Tekrar yok & 0.944 & 0.25 & 2.78 & 1.28 \\
\hline Renkli- Renksiz & 0.968 & 0.38 & 2.72 & 1.02 \\
\hline Çeşitlilik Var- Çeşitlilik Yok & 0.972 & 0.41 & 2.91 & 1.16 \\
\hline Doğal- Doğal Değil & 0.977 & 0.45 & 3.01 & 1.19 \\
\hline Büyük Ölçekli- Küçük Ölçekli & 0.964 & 0.33 & 2.92 & 1.11 \\
\hline Dengeli- Denge Yok & 0.908 & 0.15 & 3.26 & 1.07 \\
\hline Bütün Bileşenlere Verilen Cevap & 0.959 & 0.31 & 3.00 & 1.21 \\
\hline
\end{tabular}

görülmektedir (Cronbach $\alpha=0.97)$. Uzmanların en az hem fikir olduğu konu dengedir (Cronbach $\alpha=0.90$ ).

$\mathrm{Bu}$ aşamada kullanıcıların ve uzmanların beğeni sorusuna verdikleri cevapların ortalamaları alınmıştır. Alınan ortalama değerlere göre fotoğraflar en çok beğenilenden en az beğenilene doğru sıralanmıştır. Bu değerlere göre oluşan fotoğraf listeleri kullanıcılar ve uzmanlar için ayrı ayrı verilmiştir (Şekil 2, Şekil 3).

Buna göre kullanıcıların en çok beğendiği fotoğraf mazılardan oluşan bir tasarımı gösteren "Fotoğraf 14" (4.47) olurken uzmanların en çok beğendiği görsel soliter bir ağacı gösteren "Fotoğraf 19" 'dur (4.39). 


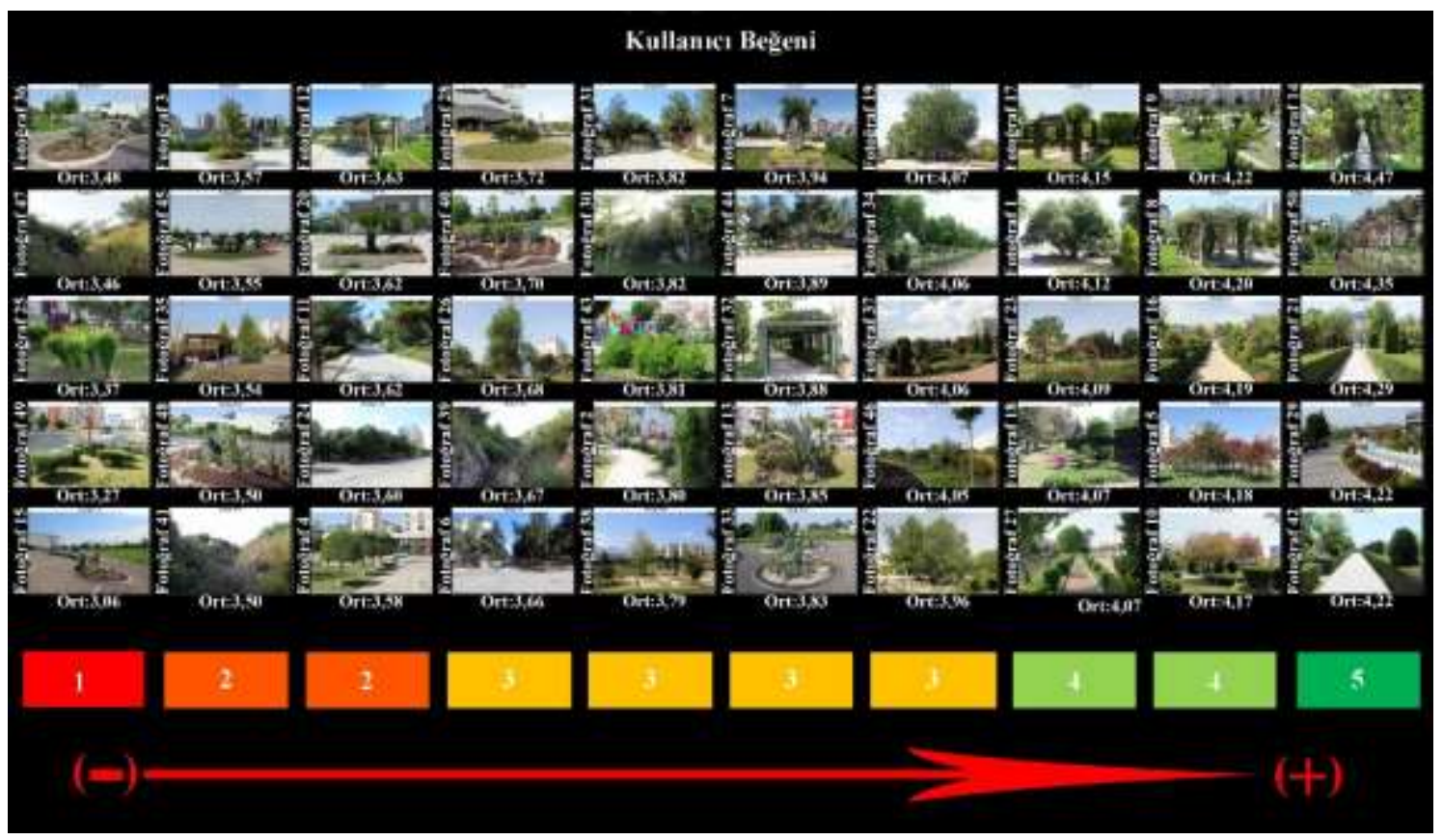

Şekil 2. Kullanıcıların beğeni düzeylerine göre fotoğrafların sıralanışı.

Figure 2. Preferences of lay persons.

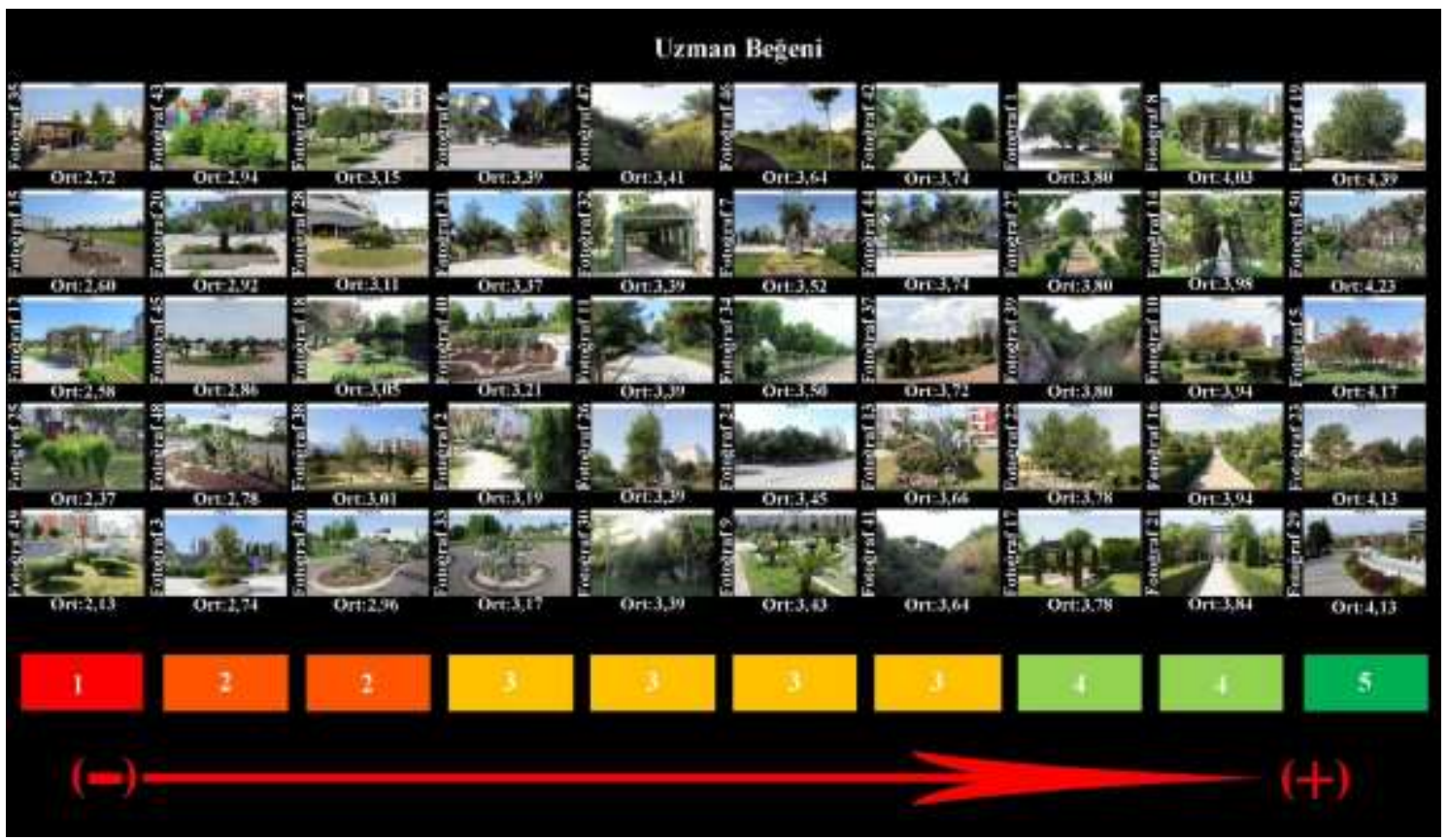

Şekil 3. Uzman peyzaj mimarlarının beğeni düzeylerine göre fotoğrafların sıralanışı.

Figure 3. Preferences of expert landscape architects.

Çalışmanın bu aşamasında uzmanların fotoğraflara ilişkin beğeni puanlarının ortalaması bağımlı değişken olarak alınarak, peyzaj mimarlarının tasarım unsurlarına verdikleri cevapların ortalaması bağımsız değişken olarak tanımlanmış ve aşamalı regresyon analizi uygulanmıştır. Analizin sonuçları Çizelge 4'te görülmektedir.

Buna göre regresyon analizinin üç aşamada tamamlandığ ve beğeniye ilişkin varyansa katkıları bakımından üç değişkenin önemli tahminleme değişkeni olduğu görülmektedir. Analize ilk aşamada peyzaj mimarlarının beğenisinin \%72.5'ini açıklayan denge unsuru alınmıştır. İkinci aşamada ise, açıklanan varyansa anlamlı katkı getiren vurgu unsuru değişkeni alınmıştır. Üçüncü aşamada ise yine varyansa anlamlı katkı getiren doğallık unsuru alınmıştır. Vurgu unsuru uzmanların beğenisine ilişkin \%11'lik bir katkı sağlamıştır. Doğallık unsuru ise uzmanların beğenisine \%8'lik bir katkı sağlamıştır. Regresyon katsayılarının işaretine bakıldığında her üç değişken ile uzmanların beğenisi arasındaki ilişkinin pozitif olduğu görülmektedir. Bu üç değişken birlikte, 
uzmanların beğenisinin toplam varyansının \%91.5'ini açıklamaktadır.

Buna göre üç tasarım unsuru ("Denge", "Vurgu" ve "Doğallık") regresyon modelinde anlamlı bir etken olarak görülmektedir. Yani peyzaj mimarlarının bitkisel tasarım beğenisini en çok etkileyen tasarım unsurları "Denge", "Vurgu" ve "Doğallık" "tır. Bu analiz sonucunda uzmanların beğenisine şu formülle ulaşılabilinir; Uzman Beğeni $=-0.356$ (Sabit) + 0.565 (Dengeli) $+0.420($ Vurgulu $)+0.206$ (Doğal) .

Çalışmanın bu aşamasında kullanıcıların fotoğraflara ilişkin beğeni puanlarının ortalaması bağımlı değişken olarak alınarak, peyzaj mimarlarının tasarım unsurlarına verdikleri cevapların ortalaması bağımsız değişken olarak tanımlanmış ve aşamalı regresyon analizi uygulanmıştır. Analizin sonuçları Çizelge 5'de görülmektedir.

Buna göre regresyon analizinin iki aşamada tamamlandığ ve beğeniye ilişkin varyansa katkıları bakımından iki değişkenin önemli tahminleme değişkeni olduğu görülmektedir. Analize ilk aşamada kullanıcıların beğenisinin \%43.4'ünü açıklayan denge unsuru alınmıştır. İkinci aşamada ise, açıklanan varyansa anlamlı katkı getiren vurgu unsuru değişkeni alınmıştır. Vurgu unsuru kullanıcıların beğenisine ilişkin \%15.8'lik bir katkı sağlamıştır. Regresyon katsayılarının işaretine bakıldığında her iki değişken ile kullanıcıların beğenisi arasındaki ilişkinin pozitif olduğu görülmektedir. $\mathrm{Bu}$ iki değişken birlikte, uzmanların beğenisinin toplam varyansının\%59.2'sini açıklamaktadır.

Buna göre iki tasarım unsuru (Denge ve Vurgu) regresyon modelinde anlamlı bir etken olarak görülmektedir. Yani kullanıcıların bitkisel tasarım beğenisini en çok etkileyen tasarım unsurları Denge ve Vurgudur. Bu analiz sonucunda kullanıcıların beğenisine şu formülle ulaşılabilinir; Kullanıcı Beğeni $=2.123$ (Sabit) $+0.312($ Dengeli $)+0.227($ Vurgulu $)$.

\section{Tartışma ve Sonuç}

Anketlerde fotoğrafların kullanıcı üzerindeki etkisi ile kullanıcı ve peyzaj mimarları tarafindan yapılan yorumlar ve daha önce yapılmış olan çalışmalar (Zube ve ark. 1987) fotoğraflardaki peyzaj tercihleriyle alanın içindeki peyzaj tercihlerinin farklılaşmadığını göstermektedir. Kullanıcılar tıpkı mekânın içindeymiş gibi yorumlarda bulunmakta ve fotoğrafları detaylı şekilde incelemektedir. Ayrıca kullanıcılar ile peyzaj mimarlarının peyzaja ilişkin tercihlerini etkileyen etmenlerden ikisi ortak iken (denge ve vurgu) peyzaj mimarlarının tercihini kullanıcılardan farklı olarak doğallık unsuru da anlamlı şekilde etkilediği saptanmıştır. Bu bulgular çevre ile ilgili ekolojik bilginin çevreye ilişkin tercihleri etkilediğini savunan ekolojik estetik teorisini (Nassauer 1997) destekler niteliktedir.

Elinç (2011), Alanya ilçesinde yaptığı çalışmada, manzara güzelliği değişkeni ile ölçtüğü bütün ölçütlerin (Uyumluluk, doğallık, bakımlılık, karmaşa, düzen, hareketlilik, heyecan vericilik ve güvenlik) bütün fotoğraflarda anlamlı bir korelasyon ilişkisine sahip olduğunu saptamıştır (Elinç 2011). Doğallığın ise sadece peyzaj mimarlarının görsel tercihlerinde etkin bir unsur olduğu saptanmıştır. Dinçer (2011) yaptığ çalışmada uzmanların beğenisini anlamlı olarak etkileyen unsurlar olarak oran ve vurguyu bulduğunu belirtmiştir (Dinçer 2011). Konyaaltı'nda yapılan çalışmada da vurgu, hem peyzaj mimarları için hem de kullanıcılar için beğeniyi anlamlı şekilde etkileyen bir unsur olarak ortaya çıkmıştır. Ancak oranla ilişkili görülebilecek olan ölçek kavramı bu çalışmada anlamlı bir değişken olarak karşımıza çıkmamıştır. Bunun yanında yine Dinçer (2011), yaptığı testlerde dengeyi peyzaj tasarımının beğenilmesine etki etmeyen, yani anlamsız bir değişken olduğunu saptamıştır. Ancak Konyaaltı'nda yapılan bu çalışmada denge hem kullanıcılar için hem de peyzaj mimarları için beğeniyi etkileyen anlamlı bir değişkendir.

Bir diğer kültürel teori olan Biçimsel Estetik Teori'ye (Bell 1999) göre peyzajın biçimsel (formal) özellikleri peyzajların tercih edilmesini anlamlı şekilde etkilemektedir (Bell 1999). Bu çalışma kapsamında tüm gruplarda vurgu ve denge unsurlarının tercihleri anlamlı şekilde etkilediği bulunmuştur. Buradan hareketle çalışmanın bu teoriyi destekleyen bulgulara sahip olduğu söylenebilir.

Ancak doğal çevrelerin kent özelinde nasıl tasarlanması gerektiğine ilişkin bitkisel tasarıma yönelik çevre estetiği çalışmaları oldukça az sayıdadır. Bunun yanında bu çalışmalar doğal alanların uygulayıcısı profesyoneller olan peyzaj mimarlarına ulaşmamaktadır.

Çizelge 4. Uzmanların beğenisinin tahminlemesine ilişkin aşamalı çoklu regresyon sonuçları.

Table 4. Results of regression analyses of preferences of experts.

\begin{tabular}{lccccccc}
\hline TasarımUnsuru & $\mathrm{R}$ & $\Delta \mathrm{R}^{2}$ & $\mathrm{~B}$ & $\mathrm{SH}_{\beta}$ & $\beta$ & $\mathrm{T}$ & $\mathrm{p}$ \\
\hline 1.Dengeli & 0.852 & 0.725 & 0.565 & 0.063 & 0.499 & 8.914 & 0.000 \\
2.Vurgulu & 0.914 & 0.110 & 0.420 & 0.044 & 0.493 & 9.549 & 0.000 \\
3.Doğal & 0.956 & 0.080 & 0.206 & 0.031 & 0.330 & 6.550 & 0.000 \\
Sabit & - & - & -0.356 & 0.172 & - & -2.065 & 0.045 \\
\hline Toplam: $\mathrm{R}^{2}=0.915$ & $\mathrm{~F}(3-46)=164.512$ & $\mathrm{P}=0.000$ & & & & &
\end{tabular}

Çizelge 5. Kullanıcıların beğenisinin tahminlemesine ilişkin aşamalı çoklu regresyon sonuçları.

Table 5. Results of regression analyses of preferences of lay-persons.

\begin{tabular}{lccccccc}
\hline Tasarim Unsuru & $\mathrm{R}$ & $\Delta \mathrm{R}^{2}$ & $\mathrm{~B}$ & $\mathrm{SH}_{\beta}$ & $\beta$ & $\mathrm{T}$ \\
\hline 1.Dengeli & 0.659 & 0.434 & 0.312 & 0.071 & 0.460 & 4.416 \\
2.Vurgulu & 0.769 & 0.158 & 0.227 & 0.053 & 0.444 & 4.260 \\
Sabit & - & - & 2.123 & 0.218 & - & 9.757 \\
\hline Toplam: $\mathrm{R}^{2}=0.592$ & $\mathrm{~F}(2-47)=34.085$ & $\mathrm{P}=0.000$ & & & &
\end{tabular}


Yapılan literatür çalışmasında bitkisel tasarımların tasarımcılar açısından biçimsel estetik unsurları bakımından 6 başlık altında incelendiği görülmüştür. Bunlar; (1) tekrar, (2) çeşitlilik, (3) denge, (4) vurgu, (5) sıra, (6) ölçektir. Ancak alanda fotoğraf çekimleri sırasında sıra öğesinin Konyaaltı bölgesinde uygulanmış toplamda 5 'e ulaşan örneği bulunamamıştır. Bunun yanında Konyaaltı bölgesinde tasarım yapılmamış doğal alanlarında bulunduğu aralıklı tekrar eden yap1 ile birlikte, tasarım yapılmış ve bitkisel tasarımda renk öğesinin önemli bir bileşen olduğu alanlar göz önüne alınarak; bitkisel tasarımların biçimsel estetik açısından 8 kriterde incelenmesine karar verilmiştir. Bu kriterler sayılacak olursa; (1) Vurgu, (2) Tekrar, (3) Aralıklı Tekrar, (4) Renk, (5) Çeşitlilik, (6) Doğallık (7) Ölçek ve (8) Denge'dir.

Çalışmanın sonuçlarını genellemeden önce çalışmanın diğer sınırlamaları üzerinde durmak faydalı olacaktır. Çalışma Konyaaltı bölgesindeki kullanıcılarla, Konyaaltı bölgesinden çekilen fotoğraflarla gerçekleştirilmiştir. Antalya kentinin bütün sakinlerinin en çok kullandığı kent parkı olan Atatürk Kültür Park ve kullanıcıları bu çalışmanın kapsamı dışında kalmaktadır. Atatürk Kültür Parkı kentin bütün kesimleri tarafından beğenilerek kullanılan kozmopolit bir parktır. Konyaaltı bölgesinde parklar ise daha çok Konyaaltı bölgesi sakinlerine hitap etmektedir. Bu yüzden çalışmanın sonuçları yerel düzeydedir. Bunun yanında ankete katılan peyzaj mimarlarının büyük çoğunluğu Akdeniz üniversitesi mezunudur. $\mathrm{Bu}$ yüzden peyzaj mimarlarına ilişkin sonuçların genellemesi de buna göre yapılmalıdır. İleriki çalışmalarda, çalışılan kentin bütününü mekânsal ve kullanıcı bazında örneklemeyle, yani daha geniş bir örnekleme daha güvenilir sonuçlara ulaşmayı sağlayacaktır.

Bitkiler ile oluşturulmuş mekânda denge unsurunun varlığ mekâna ilişkin tercihleri olumlu yönde etkilemektedir. Bu durum hem kullanıcı hem de peyzaj mimarları için geçerlidir. Bunu yaratabilmek için tasarımcı ve plancılar zıt asimetrik tasarımlar yerine mekânda kullanılan objelerin birbirine göre dengesini koruyan dengeli tasarımlar gerçekleştirmelidir. $\mathrm{Bu}$ durum hem kullanıcılar için tasarlanan parklarda hem de jürisinde peyzaj mimarı bulunan yarışmalarda geçerlidir. Mekânda çok aşırıya kaçmadan kullanılan bir vurgu unsurunun varlığı mekâna ilişkin tercihleri olumlu yönde etkilemektedir. Vurgunun mekânda uygun şekilde kullanılması için tekdüze, tekrar eden tasarımlardan kaçınılmalı ve kullanıcıyı bir noktaya çeken vurgu noktalarında farklı bitkisel materyal kullanımına gidilmelidir.

Kullanıcılar ile peyzaj mimarlarının arasındaki en temel fark tasarımda doğallığa olan yaklaşımlarıdır. Peyzaj mimarlarının bitkisel tasarımları beğenmesinde o tasarımın doğallığı önemli bir unsur olarak karşımıza çıkarken kullanıcılarda vurgu ve denge gibi biçimsel özellikler tercihleri etkilemektedir. Vurgu ve denge peyzaj mimarlarının tercihlerini de etkileyen biçimsel özelliklerdir ancak peyzaj mimarları kullanıcılardan farklı olarak doğallığa ayrı bir önem vermektedir.

\section{Teşekkür}

Bu çalışma Akdeniz Üniversitesi Fen Bilimleri Enstitüsü bünyesinde gerçekleştirilen "Bitkisel Peyzaj Tasarımlarının Değerlendirilmesinde Estetik: Antalya Konyaaltı Bölgesi" başlıklı tez çalışmasından üretilmiştir. Bu bağlamda başta tez izleme komitesinde katkılarına minnettar olduğumuz, Prof. Dr. Ebru ÇUBUKÇU ile Prof. Dr. Kemal Reha KAVAS hocalarımıza teşekkürü bir borç biliriz.

\section{Kaynaklar}

Appleton J (1975) The experience of landscape. Revised Edition, Wiley, England.

Bell S (1999) Landscape: Pattern, perception and process. Routledge, England.

Bourassa SC (1991) The aesthetics of landscape. Belhaven press, London, pp. 168.

Cimprich BE (1992) Attentional fatigue following breast cancer Surgery. Research in Nursing \& Health 15: 199-207.

Çakcı I (2007) Peyzaj planlama çalışmalarında görsel peyzaj değerlendirmesine yönelik bir yöntem araştırması. Doktora Tezi, Ankara Üniversitesi, Fen Bilimleri Enstitüsü, Ankara.

Dinçer AA (2011) Görsel peyzaj kalitesinin "biçimsel estetik değerlendirme yaklaşımı" ile irdelenmesi üzerine bir araştırma. Yüksek Lisans Tezi, Ankara Üniversitesi, Fen Bilimleri Enstitüsü, Ankara.

Ekşioğlu G (2010) Çevre estetiğinin konut fiyatları üzerindeki etkisinin hedonik fiyat yöntemi ile modellenmesi. Yüksek Lisans Tezi, 9 Eylül Üniversitesi, Fen Bilimleri Enstitüsü, İzmir.

Elinç H (2011) Görsel kalite değerlendirmesi yöntemi ile Antalya ili Alanya ilçesi Abdurrahman Alaettinoğlu ve Alanya Belediye Başkanları kent parklarının irdelenmesi. Yüksek Lisans Tezi, Selçuk Üniversitesi, Fen Bilimleri Enstitüsü, Konya.

Hartig L, Mang M, Evans G W (1991) Restorative effects of natural environment experiences. Environment and Behavior 23(1): 3-26.

Hersberger RG (1992) "A Study of Meaning and Architecture". Environmental Aesthetics: Theory, Research, Applications. Editör: Nasar, J. Cambridge: Cambridge University Press, pp. 175-194.

Kaplan S, Kaplan R, Wendt JS (1972) Rated preference and complexity for natural and urban visual material. Perception \& Psychophysics 12(4): 354-356.

Kaplan R, Kaplan S (1989) The experience of nature: a psychological Perspective. ABD Ann Arbor Michigan: Ulrich's Bookstore.

Kaplan R, Kaplan S, Ryan RL (1998) With people in mind: Design and management of everyday nature. Washington ABD: Island Press.

Meinig DW (1979) Introduction, In: D. W. Meinig (Editor), The Interpretation of Ordinary Landscapes, Geographical Essays, Oxford University Press, USA, pp. 1-7.

Nasar JL (1992) Visual preferences in urban street scenes a crosscultural comparison between Japan and the United States. Environmental Aesthetics: Theory, Research, Applications. Editör: Nasar J. Cambridge: Cambridge University Press, pp. 260-274.

Nassauer JI (1997) Cultural sustainability: Aligning aesthetics and ecology. In J. I. Nassauer (Ed.) Placing nature: Culture and landscape ecology, DC: Island Press. Washington, pp. 67-83.

Orians GH (1980) Habitat Selection: General theory and applications to human behavior. In: J. S. Lockard (editör), The Evolution of Human Social Behavior, Elsevier, New York.

Tennessen CM, Cimprich BE (1995) Views to nature: Effects on Attention. Journal of Environmental Psychology 15(1): 77-85.

Türkiye İstatistik Kurumu (2016) "Adrese dayalı nüfus sayım sistemi”. www.tuik.gov.tr. Erişim 6 Mart 2016.

Ulrich RS (1984) View through a window may influence recovery from surgery. Science 224: 420-422.

Wilson EO (1984) Biophilia. Harvard University Press, USA, pp. 157.

Zube EH, Simcox DE, Law CS (1987) Perceptuall and scape simulations: History and Prospect. The Landscape Journal 6: 62-80. 